\title{
Complementarity and cohesion of the sophiologic and scientific vision of creation*
}

\section{(Komplementarność i spójność sofiologicznej i naukowej wizji stworzenia)}

\author{
JAN P. STRUMIŁOWSKI OCIST \\ Wyższe Seminarium Duchowne w Katowicach-Panewnikach \\ jancist@gmail.com \\ ORCID: 0000-0003-1547-8309
}

\begin{abstract}
The rapid development of empirical science (physics, biology) and theoretical disciplines (theoretical physics) related to them, results in many theories on the origin, evolution and nature of the world, sometimes interpreted as contradictory to the theological conception. Consequently, under the influence of these achievements, within theology itself a position on the autonomy of both domains and on their complementarity seems to be more and more popular. With regard to this question, it is theology that should present the possibility of an understanding of the revealed truths such that they could coexist with scientific discoveries.

Based directly on biblical texts, the sophiological vision of the origin and nature of the world seems to be very interesting among other theological conceptions regarding this question. The present article attempts to confront the presumptions of sophiology regarding the eternal creative Wisdom with the scientific theory of the world's nature
\end{abstract}

This publication was made possible through Grant OPUS14 Number 2017/27/B/HS1/01634 from the National Science Centre (NCN).

ScientiaetFides 7(1)/2019, 207-225 
(i.e. its laws), its development (evolution, accidentality of events) and on human existence (e.g. liberty) in order to demonstrate the possibility of the coexistence of these discourses without contradiction.

Keywords: Sophiology; Wisdom; creation; Trinitarian ontology; cosmology; evolution; science and religion.

Streszczenie. Bardzo szybki rozwój nauk empirycznych (fizyka, biologia), oraz związanych z nimi dziedzin teoretycznych (fizyka teoretyczna) prowadzi do powstawania teorii dotykających zagadnień początku, rozwoju i natury świata, które bywają interpretowane jako opozycyjne w stosunku do koncepcji teologicznych. Z kolei na gruncie samej teologii, pod wpływem tychże odkryć, coraz popularniejsze wydaje się być stanowisko opowiadające się za uznaniem autonomii obu dziedzin oraz ich komplementarności. W obliczu tak rozumianej zależności po stronie teologii leży obowiązek zdania sprawy z możliwości takiego rozumienia prawd objawionych, by mogły one współistnieć z odkryciami naukowymi.

Wśród różnych koncepcji teologicznych dotykających zagadnienia genezy i obrazu świata ciekawe ujęcie prezentuje wywodząca się wprost z tekstów biblijnych wizja sofiologiczna. Niniejszy artykuł dokonuje konfrontacji założeń sofiologii na temat odwiecznej Mądrości stwórczej, z tezami naukowymi w odniesieniu do kształtu świata (praw nim rządzących), jego rozwoju (ewolucji, przypadkowości zdarzeń), oraz istnienia człowieka dotykającego problemu ludzkiej wolności, w celu ukazania możliwości współistnienia tych dyskursów, bez popadania w sprzeczność.

Słowa kluczowe: sofiologia; Mądrość; stworzenie; ontologia trynitarna; kosmologia; ewolucja; nauka i religia.

\section{Introduction}

In the $21^{\text {st }}$ century when science has become ever more fragmented as it co-exists with the paradigm of pluralism and diversity. This provokes an ever greater need for interdisciplinarity and theology should not ignore the scientific conceptions of the beginning and evolution of the cosmos nor biological evolution. Theology is called to interpret theologically those phenomena and such interpretation should result in an integrated view of creation, and more accurately - of an act of creation in time which respects the autonomy of natural laws (Pabjan 2016, 12).

A historical glance at the formation of interdisciplinary reflexion in the context of theology and empirical sciences demonstrates that it may take extreme forms. Synthetically, one should enumerate four possibilities of 
interaction: conflict, independence, dialogue, integration (Barbour 1988, 21-48). The history of various errors respecting the autonomy of the sciences branches and theology, as well as methodological differences and the otherness of the formal object, all that suggests that acknowledgement of the autonomy of both ways of perception, analysis and description is the most appropriate attitude. One should be aware, however, that an exhaustive description of the world is possible only thanks to an interdisciplinary attitude, because the scientific description and the theological one do not enter in conflict, but, instead respect their proper competences, and give a coherent and complementary picture (Pabjan 2016, 41-46).

This article, assuming this point of view, attempts to analyse two descriptions of the beginning of the world: the theological one - based on a very large variant of the theological doctrine about the origin and existence of the world, as presented in sophiologic texts; and the scientific one - also with no adhesion to a specific theory, but rather looking largely and generally at different scientific solutions and taking into account the problems that could arise in a theological context.

In fact, the article tries to consider those conflicting areas by asking whether those problems are unsolvable really or apparently, that is: whether they can be interpreted in the light of autonomy and complementarity mentioned above. In other words, we intend to ask whether the theological view of the world is so much universal that it could be harmonized with scientific views?

\section{Sophiological vision of creation}

The sophological idea finds its origin directly in the biblical sapiential books, especially in Proverbs, Sirach and Wisdom (Bolewski 2012, 54-82). The biblical texts say that Wisdom is the archetype of every divine activity that reveals God's creative plan, that He eternally knew and that He eventually accomplished in the history of creation and salvation.

That biblical basis was then developed by the Fathers of the Church and by ancient Christian writers. The first apologists, Saint Justin for example, 
identified Wisdom with the pre-existing Son of God. According to him, the Logos is the principle of creation, actively cooperating with the Father (Justyn Męczennik 1926, no. 61, 1). Nonetheless, in Christian antiquity Wisdom was also identified with the Holy Spirit. Such was the opinion of Saint Irenaeus of Lyon written in Adversus haereses (Irénée de Lyon 1982, no. II, 30, 9), however it was less popular than the Logos position.

One may observe that Saint Clement of Alexandria connects Wisdom with the hypostasis of the Son and tries to distinguish the uncreated Wisdom from the created one. According to him, Wisdom means first of all "the thoughts of God" present in the Logos, and then their "hypostased species" identical with the laws of cosmos (Clément d'Alexandrie 1976, no. I, 77, 3). According to Origen, Wisdom was firstly "created" with previously defined rules that govern the whole world. Furthermore, Wisdom understood in this way is identical with the Word of God. Obviously, in the context of that interdependence, the expression of Origen used to explain the beginning of Wisdom, should be clarified. Although Origen says that Wisdom "was created" (creata esse), he adds that assigning a beginning to Wisdom, is a blasphemy (Origen 1857, no. I, 2, 3). For that reason, he thereafter speaks about a begetting, which should not be understood as a carnal procreation, but as an eternal generation ${ }^{1}$. It follows that some kind of scheme of all creation is contained in the eternal Son (Word). Creation as determined and shaped had been residing eternally in the Son, who is identical with Wisdom, i.e. the ideas of everything that will exist reside in Wisdom (Orygenes 1996, no. $1,4,4)$.

This type of position has taken various forms over history. The relationship of Wisdom to the triune God has been differently interpreted, especially in oriental theology which has many various interpretations. For instance, V. Solovyov considered Sophia (created) as a realised idea, some kind of "flesh" or "matter" of the Divinity, permeated with the element of unity,

1 “Est namque ita aeterna ac sempiterna generatio" (Origen 1857, no. I, 2, 4), no. I, 2, 4). That interpretation is in accordance with the Hebrew meaning of the term used to designate Wisdom in Proverbs: quanami, that can be also understood as "He begot" (Bolewski 2012, 66-67). 
which attains its full expression in Christ (Stolovič 2008, 220-221). The world that tends purposefully to that fullness (which constitutes, according to Solovyov, the total process of theandric evolution) is subordinated to the uncreated Sophia, that is to the eternal Wisdom of God (Walicki 2005, 535). S. Bulgakov developed the question in a similar manner. He conceived Sophia as humanity's superindividual basis that exists eternally in God. According to that conception, the creative act was some kind of projection of proper ideas on the outside (Walicki 2005, 798). Thus, in such a context, Sophia herself may be considered as a perfect image of three-hypostatic Triune God, and simultaneously, as a model of every representation, i.e. as a model of the fullness of creation (Bulgakov 2012, 53), Consequently Sophia is some kind of agent in Providence, transforming chaos into cosmos (Valliere 2001, 260-264).

Apart from the heterodox understanding of Sophia ${ }^{2}$ as having an anthropomorphic expression, one may observe that the very realisation of the world is somehow a reproduction in created categories of the ideal model that exists eternally in God's Wisdom. Moreover, that realisation does not consist in some repetition of the transcendent design in created categories, but it consists in a mutual penetration of the divine and the created, insofar as Sophia is the soul of the world (Walicki 2005, 536). However, that mutual penetration suggests some adequacy between the uncreated Wisdom and creation; the concept of created wisdom co-existing with the uncreated Wisdom solves that difficulty. The created wisdom is a result of God's creative action, but on the other hand it differs from the created world for it constitutes its "sense" or the "mystery of its order" and as such, it is some kind of category revealing the mystery of creation (Bolewski 2012, 64-65).

2 The idea of sophiology, especially in many Russian theologians of the 19th and 20th century, takes a heterodox form. We may enumerate among the most doubtful questions: liquidation of borders between the divine and the human and giving the Sophia the status of a divine hypostasis. It does not mean that it cannot be understood in an orthodox way. For example, Pavel Florensky seems to avoid those errors, as he does not hypostasise the Sophia, when he calls her "triune Love of God" that has been poured out within our hearts through the Holy Spirit. Also, he considers her the primitive nature of creation, but in the sense that only what is "known" by God exists and besides, he makes a clear distinction between the uncreated Sophia and the created one (Флоренский 1990, 326-327). 
Doubtless, in such sophiology one may already perceive some elements of the idea that the creation and evolution of the world come about according to the eternal design, which demonstrates that the cosmic process is conceived as purposeful. Solovyov states simply that the world's pursuance of a universal unity (which is identical to an ever more perfect realisation in creation of the eternal design of God's Wisdom), manifests itself firstly as a brute force of the laws of nature (gravity, chemical laws etc.), secondly as the rule of organisation of organic life, and finally as conscious and free human activity (Walicki 2005, 536-537).

Therefore, within the sophiological idea one can learn that not only the rules governing the world find their source in the eternal uncreated Wisdom, but also the realisation of the ideas (i.e. principles that are in God and realise themselves in creation) finds its highest purpose in the perfect humanity having its model in Christ. It seems, that the sophiological vision considers God not only as the creative principle, but also the principle of the dynamism of creation and consequently, it concerns both cosmology (considered as scientific reflexion upon creation) and evolution (the scientific theory of creation development).

That purposefulness may be interpreted differently. Although, at first glance it suggests, that the sophiological categories organise the rules governing the world's existence and evolution (which recalls a certain harmony between sophiology and intelligent design theory), this is not the exclusive manner of understanding the participation and realisation of God's order in creation. More importantly, this manner seems to ignore the ontological difference between God and creation.

Thus, in order to correctly understand that participation, it seems helpful to recall Pavel Florensky's interpretation of sophiological statements. He attempts to justify the connexion between Sophia, conceived as the eternal creative design of God, and the Sophia created which is the order of creation realised according to the God's design. Florensky stresses that the world existing in time participates in the eternal "now" of God (Флоренский 1990, 327), and that opinion corresponds with a theory that within Western theology - may be found and deduced from Aquinas' teaching. According to 
him, the world is some kind of space-time image of God (Seckler 1964, 81). That emphasis upon the difference between the temporary existence of the world and the timeless existence of God seems to be an essential premise for such an interpretation of God's creative activity that avoids the error of intelligent design.

\section{Conflict area between the theistic and the scientific view of the world}

History demonstrates that on the ground of theology, the deposit of the revealed truths was sometimes misunderstood. The biblical narration of the creation was placed in to the sphere of quasi-dogmas (as a classical example of such an error we may recall the opposition to heliocentrism because of its incompatibility with the biblical text). Today, errors of that kind are considered an obvious abuse. However, besides those errors, we may witness other theological misconceptions that disturb the autonomy and competence of the empirical sciences. They no longer result from an oppositional attitude, but from a too hasty proving of coherence, without taking into account the methodological differences and the differences of the formal object of both branches of science. Filling gaps in the scientific view of the world with God's activity may be counted among such errors. The problem is sharply visible already in pope Pius XII's apologetic proving of God's existence which was based on the Big Bang theory (Pabjan 2009, 277-294), although that theory neither denies nor proves God's existence (Ferguson 2004, 97) in spite of its various forms. It is so, even if we assume the existence of cyclical Universes or the no-boundary Universe conception of S. Hawking (Hawking 1998), because such models are not in opposition to the Christian teaching about the creatio continua that may be interpreted as some kind of variant of the creatio ex nihilo (Strumiłowski 2016, 133-134), which is in turn a result of the foregoing sophiological models.

The sophiological view seems therefore to be immune to the implication of that kind, as Wisdom (or the eternal design of God which is in some sense the content of Wisdom) refers rather to the world's form (rules that govern 
it) than to its origin. Only in that field we may legitimately ask the question whether it is justified to suppose that the rules governing the world and its very structure are some reflexion of God's eternal design. The problem seems to be resolvable on at least at three levels:

1) in the most general sense: the laws of physics that determine the world's shape are some reflexion of God's design or God's essence.

2) in a more in detailed sense: Is it possible to harmonize the laws of cosmic and biological evolution, where the categories of random events succeed according to a certain regularity or are prevailing ${ }^{3}$, with the purposefulness of the Universe that is suggested by the sophiological view, which assumes the existence of some eternal matrix of creation (Heller 2014b, 166)?

3 ) in the most detailed sense: Does God's eternal design or the world's image concern every single person in his or her particularity? It already seems to touch the problem of human liberty ${ }^{4}$. For, if the world is eternally designed in its smallest details, the question arises whether the world is some kind of "eternally shot film", projected on "created" categories. If so, every event in the Universe is precisely

3 In the context of cosmic evolution, the random events designate the set of all chemical and physical events that happen within the physical laws. The randomness of events in that context led to that form of the Universe as we have today: where there is the solar system with our planet on which arose life. Given the randomness of events a similar system would have arisen, but without a planet like ours. In turn, in the context of biological evolution, the random events designate the mutations caused by multiplication of the organisms within the natural selection. The set of random events within that law would have resulted also in completely different species than those we know, homo sapiens included.

4 We do not discuss here the question of determinism of human freedom nor do we analyse the neuropsychological constitution of the mind in order to discern whether human activity is determined by the biological-physical-chemical laws whereas the free will is merely an illusion. However, if it turned out that human liberty were determined by more fundamental laws, we could acknowledge that, according to the sophiological conception, the world would be a reflexion of God's eternal design in every single detail. After resolving the antinomy of the second level, it would not require any more analysis. Yet, we assume that the human will is undetermined, i.e.: that, even if it were wholly determined by the brain and as such could be described by neuroscience, those laws would allow the bodily-constituted mind to make free decisions. To be sure, it needs to be justified which we will try to do at the third level of argumentation. 
determined by the will of God, with no exclusion of the events that we used to consider as random or dependent on human freedom (Ferguson 2004, 30-33).

Resuming the three above points and demonstrating their coherence, we may say, that the first one concerns the inter-dependence between the divine Logos/Sophia and the laws of nature. The theistic interpretation that considers the order of the world as a purposeful Creator's activity and admits the possibility of other worlds with other rules, makes us ask the question about the coherence between the Logos/Sophia and the coincidence and randomness theory. It constitutes the second of the above points. In the context of self-conscious beings who integrate the sphere of random events with the sphere of their freedom, we come to the third point which determines the harmony between the Logos/Sophia and human freedom. However, it is necessary to reflect whether there is such a model of Divine Wisdom interaction with the created world, that could be integraated with the three above levels of the world's existence.

Nevertheless, we should add that the detection of that interaction is in no case any proof of the Divine mind: in other words, it does not prove God's existence nor even the truth of that interaction. Detection of such a model is merely an argument that, potentially, defines Wisdom's connexion with the world as rationally and potentially possible. It suggests also that there is no contradiction between the scientific and religious view of the world and that faith is rational.

\section{The compatibility condition on the three levels of reflexion}

The first level of our reflexion consists in the question whether the existence of laws of physics justifies the existence of the Universe to the extent that they exclude God's existence. Of course, among the physical theories there are some which attempt to explain the world's existence thoroughly, that is, without assuming its origin (the origin suggests some divine intervention), which seems to reduce the legitimacy of the thomistic argument of the first cause (Aquinas 2012, no. I, q. 2, a. 3). Obviously, that interpretation, 
identifying God with the eternal rules determining the eternally-existing world, is so naïve, that it does not take into account the transcendent nature of God and, as a result, it explains why the world can exist eternally, but does not explain why the world exists (Ferguson 2004, 147-148). Clearly, noticing that difficulty does not prove God, but states that science cannot prove His nonexistence either. What is more, it raises another philosophical problem.

The formulation of a mathematical conception that attests the eternal mechanics of the world's existence (e.g.: the above-mentioned no-boundary Universe model) does not prove that it is the only possible mathematics (or physical theory). In that context the question arises why the laws of physics are such and not other. The question is so far relevant that we may observe that even the smallest change of the physical constants would not have made possible such an Universe where conscious beings could arise (Ferguson 2004, 163). That seems to suggest some creative purposefulness and God's design, however it is not evident. The anthropic principle (for it about that principle), contrary to the first impression does not prove the necessity of the existence of a God who purposefully designed the Universe in such a manner that the intelligent and conscious beings could arise. The principle just states that the Universe could have another form but we could not observe it, because we would not have existed. We observe such rules for we exist. Our existence is strictly connected with such rules and laws, because they make possible our existence (Heller 2014a, 136-137). Thus, the anthropic principle neither attests nor excludes the existence of God. Consequently, in the sophiological contexts, such interpretation does not contravene the coexistence of divine design with scientific theories. Nonetheless, although the sophiological principle stating that the world has such a form and not another form because it was eternally so in the Divine mind, remains actual, it is also consistent with the sophiological principles and what theoretical physics postulates, that another alternative world is possible.

However, the converse question is also very important: Does not the assumption identifying God (or His eternal design immanent to Him) with mathematical laws provoke, at the junction of science and theology, the same phenomenon as it was at the junction of philosophy and theology, 
which was called by Heidegger "onto-theology"? Do not we, by illegitimate identification of laws discovered by science with God, narrow the notion of God, just as it is narrowed when it is identified with absolute philosophical principles, which makes us no longer think about God, but about an idol (Marion 1977, 22-30)?

Thanks to the absolute simplicity of God, His "thought" is identical with His essence. That suggests inevitably that we are doomed to such identification. On the other hand, the opinion that the laws of nature reflect the essence of God seems to result in a certain limitation of God and rendering Him an idol. Still, theology (especially Oriental theology - which is relevant as we are treating sophiology) solves that difficulty by stating that although the laws of nature (logics, mathematics) come from the essence of God, they are not its accurate transmission, but a mere analogous reflexion, for God, in relation to the world's laws is metalogical (Obolevitch 2011, 87-88), That means that the fundamental laws of nature express somehow the nature of God, but they do not exhaust it, because God and His Wisdom are infinitely greater than the Universe.

What is curious, even in the field of science, is the question of whether the actual laws of nature (i.e. the most fundamental laws such as the laws of mathematics) are the only possible ones. Is it possible that there are alternative worlds, where the laws of logics or mathematics are totally different? Could God create an alternative world with alternative rules (Ferguson 2004, 62-63)?

In the light of that question, the possibility of the adherence of Sophia to the world opens two further levels. If Sophia (God's design) contains the potentiality of alternative worlds, our world arose in its form (from the scientific point of view) either by chance or, what leads to the second level of our discussion (i.e. Do the random events comply with God's design?), God created it purposefully and chose one possibility from an infinite number of others. As a result another question arises, whether it is possible that there is real freedom in creation (which constitutes the third level of our reflexion).

The second level concerns the coherence between the Eternal Wisdom as well as God's freedom and random events that indicate the evolution of 
the Universe toward the form that we see today. It concerns also a meeting of God's freedom or creation according to His eternal design with the laws of cosmic and biological evolution.

Of course, on the most general level, the theory of evolution, does not contradict the theistic vision of the world. The contradictions and conflicts arise usually from the lack of distinction between the theory itself and its philosophical interpretation (Pabjan 2016, 9-10), or from the lack of proper determination of the formal object of both branches.

Nevertheless, the conflict at the junction of evolution and religion may arise on a more subtle ground. For, if we agree that science answers the question of how evolution works, and religion provides the reason and sense of the human being, there remains a difficulty between the eternal creative design that demonstrates the purposefulness of the creative process and the random process that characterizes evolution.

But that contradiction arises because of a wrongly ordered metaphysics of theological reflexion. The statement that God eternally knows every future event and every future creation is erroneous, if we interpret that pre-knowledge in the perspective of time and if we conclude that the process of Universe development has been designed by that pre-knowledge. That interpretation, namely that God previously foresaw the shape of the world, tends inevitably toward the intelligent design theory. That theory interprets the process of evolution as purposeful, which makes God in some sense fictitious as it spoils the evolution with its basic feature, i.e. the random change provoked by natural selection (Kozłowski 2011, 78). Thus, we face the alternative: either evolution is a fact and we cannot talk about a previous design because of a random change, or we assume an anterior plan and we state that evolution and all its processes are somehow fictitious.

However, we have to think whether we may pass over that perspective and ask if there is a model according to which God would act freely and purposefully with no harm to the randomness of the laws of nature. The model of a non-interventional God's activity seems to fit that perspective. The model assumes and respects the autonomy of the laws of nature and simultaneously states that those laws are already a result of God's activity and that God, 
through those laws, continues to create (Pabjan 2016, 115-117). Nevertheless, that model may suggest that the evolution theory is still illusory, if we interpret it in an erroneous metaphysical perspective. For, if we acknowledge correctly the transcendence of God and the immanence of the world, but if we overlook similar features in God's activity, i.e., if we interpret his creative activity as mediated in created laws of nature and realised in time ("entangled" in time), the evolutional processes lose their autonomy, because of the lack of a common level. In that case, it is not the actual evolutional mechanisms that govern the world, but God's activity mediated in them. We witness then, in the area of evolution, a conflict of two forces and activities which results from their ontological participation in one space-time.

Things are different if we acknowledge that God and his activity do not exist in time, although God creates every moment of the space-time in His eternal "now". In that perspective, it is not so much that God knows what is going to happen and determines the processes of the Universe (which makes the evolution illusory), but rather, everything that happens and exists is immersed in the timeless "now" of God (Levering 2004, 89-91). In this way, God can be the cause of the world and its laws, which is realised in an essential creation of the world, in its total shape, with no "entangling" in the internal (temporary) dynamics of its laws (Levering 2004, 106-107), which would make evolution only fictitious.

Thus, God's existence out of time as well as His activity that creates the space-time seems to justify the possibility of autonomous laws that are not contradictory to categories such as coincidence or random event nor to the thesis of the divine origin of the world. Some versions of the sophiological model (e.g.: that of Pavel Florensky) postulate precisely such a metaphysical interpretation that is immune to that allegation.

Meanwhile, we still need to explain the possibility of harmonization between sophiology and science on the third level. The problem is even more complex. For, if the coincidence reigning in the world does not contradict the fact that every being has its origin in God's design, the statement that every human - although existing according to the evolutional random events - is known and wanted by God, seems to be legitimate. 
The questions remains, however, whether, in the context of such integration of God's design with the rules of the world, that scheme does not annihilate human liberty. It is true that the above metaphysical clarification means that fortuity does not contradict God's eternal plan, but on the other hand, a free human act does not necessarily have to fit that scheme. Then, in the perspective of the temporary world and a timeless God, His freedom and random events may coexist without contradiction, though human freedom - as the human while realising his or her freedom creates somehow him or herself and constitutes his or her form - seems to oppose the fact that we are the ones who are known eternally by God.

Unfortunately, that metaphysical clarification does not seem to resolve the problem satisfactorily. However, some thesis of Trinitarian ontology may be helpful in further clarification of our metaphysical model. It is not only possible from the sophiological point of view, but even necessary, as the sophiology itself is situated in the Trinitarian context ${ }^{5}$.

It is so, because the above mentioned opposition between human will and God's design is a consequence of a more fundamental assumption that results directly from the identification of God with the Absolute. Whereas, the Christian conception claims that God is infinitely close to the world without smallest distance or opposition and every event and every moment is somehow realised within God (Levering 2004, 89-90). That image of God, who is not opposed, but rather who is radically close to His creation, emerges from a Trinitarian ontology that is strongly connected with the sophiological conceptions. As it was demonstrated at the beginning of the present article Sophia is most often identified with Logos (the Son) and for that reason the fullness of Divine Wisdom was revealed in the world by the incarnate Son. However, in some partial form Wisdom may be revealed in every creation, for everything that exists, was created in the Son. That thesis orientates us directly toward Trinitarian ontology.

The creative perspective once situated in the context of Trinitarian ontology, the problem of opposition between the world and God ceases

5 Because theology not only benefits from metaphysics, but also modifies and clarifies it (por. Greshake 2016, 454-64). 
to exist. Just as the existence of the Son is not oppositional to the Father - rather on the contrary, as the Son is begotten of the substance of the Father - the world created in the Son does not exist in an autonomous opposition, but thanks to a participation in the existence of the Father who gives Himself, of course keeping in mind the ontological difference. Then, the existing world, that is, receiving incessantly its existence, is inscribed to the internal relations of the Trinity (Piotrowski 1999, 119) and in that way Wisdom, the domain of the Son, comes true in it. Such a conception of the relations between the Universe and God is extremely important, as it reduces the eventuality of an oppositional interpretation of the laws of nature, with no harm to their autonomy.

Accordingly, in that perspective it is a misunderstanding to interpret human freedom as oppositional with reference to God's freedom (Sokolowski 1995, 35-36). The Trinitarian ontology orders the relation between the transcendent Creator and the created world in such a way that the order of the nature and the order of created freedom realise themselves in the perspective of their transcendent source (Bernard 1967, 142). In other words, human liberty extends to the area of God's self-sharing that the human may freely accept or reject. Thus, the divine freedom that is realised in the creative act does not limit human liberty, but also it constitutes the area and condition of its realisation.

From the sophiological point of view, we may state that the creation of a human in the Son implies the eternal knowledge of his or her potential fullness (having its model in the Incarnate Son) and simultaneously the consent to the autonomy of the human, which means that human life can be realised in the existential area extended between non-existence and the fullness of existence in God. That is the condition and the space of human freedom. As to the relation analysed at the second level, namely time-timelessness, it means that, while offering to the human the potential fullness of existence, God knows already the actual form of its realisation without determining it.

Subsequently, the sophiological-trinitarian view is also immune to the antinomy of the third level. It is worth noting that the successive levels of the 
present article assumed some metaphysical modifications that suggested the direction of interpretation of the meaning of Divine Wisdom. It is also worth observing that the consequent metaphysical clarifications, while acquiring more and more detail, do not destroy what is proper and correct in the more fundamental metaphysical model. In that way, the model based on the Trinitarian ontology takes into account the relation time-timelessness of the second level and the relation determining the creation by the Creator of the first one. It demonstrates some over-competitiveness and coherence in Christian thought.

\section{Conclusions}

In the present article, the reflexion upon the connexion and possible coherence between the sophiological (theological) and scientific view of the world was done at three levels. As it was demonstrated, the shift to the next level needed a more precise theological description and even some change of ground of the theological reflexion. The first level was, as we saw, solvable at the purely philosophical ground. The coherence between the theistic and scientific view of the world could be done on the most basic metaphysical level concerning God's transcendence and the world's immanence.

The second level - where the conflict seemed to tighten as it required not only some coherence between God's plan and the logical laws of the world, but also between the purposefulness of God's mind and the randomness of the processes in the world - needed to deepen the metaphysical thought in order to confirm the meta-relativity of God's plan with regard to the world. The explanation at the second level not only confirms the intuitions of the first level, but also even radicalises them, i.e. it highlights that God actually surpasses the world in every aspect (also in such fundamental categories as the laws of nature and time). So God's existence can be in accordance both with the existence of the world and its laws explained at the first level (the laws come from God but are not identical with Him) and with what was proved at the second level: the transcendence of a timeless essence of God connected with the temporary world justifies a harmony between the purposefulness of God's mind and the random events of the world. 
At the third level in order to reconcile the opposition or the conflict between God's freedom and human freedom, we needed to render the metaphysics Trinitarian. Only the Trinitarian ontology seems to be the correct point of departure to find complete harmony.

What is important, the level of the theological thought (in that case the sophiological one) contains all three levels of the metaphysical description. It suggests that the theistic argumentation or an interdisciplinary reflexion as to the relation between science and religion remains somehow incomplete if done only in the context of philosophy of religion or natural theology. Moreover, the present article also demonstrates indirectly that dogmatic theology is a domain that not only explains the particular rules of the Christian faith, but it influences a larger reflexion and a view of the world in general. For that reason Christian theism, within the dialogue with the external world, should not be distanced from its own principles and categories, because it risks losing some of its essential features, and sometimes it loses also its important arguments that are difficult to formulate solely on the philosophical ground. In other words, the dogmas tell us not only who is God, but also suggest the concrete interpretation and understanding of the world.

The present article also states indirectly, that the confrontation of theology with science purifies the latter from its erroneous interpretations. Christian theology should thus be purified not only at the junction with philosophy, but also with other sciences. Doubtless, Revelation itself may be interpreted in many ways, which has resulted in many Christian denominations. However, in order to interpret it correctly, it seems to read the "Book of Revelation" juxtaposed not only with the "Book of rational reflexion", but also with the "Book of nature", for, as it was demonstrated at the beginning of the article, only the symphony of the different narratives can give us a fuller, that is a more beautiful, image of the world.

\section{Bibliography}

Aquinas, Thomas. 2012. Summa Theologiae: Complete Set. Place of publication not identified: Aquinas Inst. 
Barbour, Ian G. 1988. "Ways of Relating Science and Theology.” In Physics, Philosophy, and Theology: A Common Quest for Understanding, edited by Robert J. Russel, William R. Stoeger, and George V. Coyne, 21-48. University of Notre Dame Press. Bernard, Charles André. 1967. La Prière chrétienne: Étude théologique. Paris: Desclée De Brouwer.

Bolewski, Jacek. 2012. Misterium mądrości: traktat sofio-mariologiczny. Kraków: Wydawnictwo WAM.

Bulgakov, Sergir. 2012. Icons and The Name of God. Translated by Boris Jakim. Michigan: W.B. Eerdmans Pub. Co.

Clément d’Alexandrie. 1976. Le pédagogue. Translated by Henri Irénée Marrou and Marguerite Harl. Sources Chrétiennes 70. Paris: Éditions du Cerf.

Ferguson, Kitty. 2004. The fire in the equations: science, religion, and the search for God. Philadelphia: Templeton Foundation Press.

Florenskij, Pavel Aleksandrovich. 1990. Stolp i Utverzhdenie Istiny. Opyt Pravoslavnoj Teodicei v Dvenadcati Pismakh. Moskva: Pravda.

Greshake, Gisbert. 2016. Der dreieine Gott Eine trinitarische Theologie. Freiburg: Verlag Herder.

Hawking, Stephen. 1998. A Brief History of Time. New York: Bantam Books.

Heller, Michał. 2014a. Nowa fizyka i nowa teologia. Kraków: Copernicus Center Press. Heller, Michał. 2014b. Sens Życia i Sens Wszechświata: Studia z Teologii Współczesnej. Kraków: Copernicus Center Press.

Irénée de Lyon. 1982. Contre Les Hérésies. Translated by Adelin Rousseau and Louis Doutreleau. Sources Chrétiennes 293. Paris: Editions du Cerf.

Justyn Męczennik. 1926. Dialog z Żydem Tryfonem. Translated by Arkadiusz Lisiecki. Poznań.

Kozłowski, Jan. 2011. “Czy Teorię Ewolucji Można Zmatematyzować?” In Ewolucja Życia i Ewolucja Wszechświata, edited by Janusz Mączka and Paweł Polak, 75-84. Kraków: Copernicus Center Press.

Levering, Matthew. 2004. Scripture and Metaphysics: Aquinas and the Renewal of Trinitarian Theology. Malden: Blackwell Pub.

Marion, Jean-Luc. 1977. L'Idole et La Distance. Paris: Grasset.

Obolevitch, Teresa. 2011. "Linie Rozwoju Apofatyzmu w Filozofii Rosyjskiej XX Wieku (Georgij Fłorowski, Siemion Frank i Lew Karsawin).” Przegląd Filozoficzny - Nowa Seria 77 (1): 81-93.

Origen. 1857. "Peri Archon.” In Opera Omnia, by Origen, 1:115-414. Patrologia Graeca 11. Paris: Garnier et Migne.

Orygenes. 1996. O zasadach. Edited by Henryk Pietras. Translated by Stanisław Kalinkowski and Katarzyna Augustyniak. Kraków: Wydawnictwo WAM. 
Pabjan, Tadeusz. 2009. “Czy Nauka Dowodzi Istnienia Boga? Naukowa Apologetyka Piusa XII.” Studia Philosophiae Christianae 45 (2): 277-294.

Pabjan, Tadeusz. 2016. Anatomia Konfliktu: Między Nowym Ateizmem a Teologia Nauki. Kraków: Copernicus Center Press.

Piotrowski, Eligiusz. 1999. Teodramat: dramatyczna soteriologia Hansa Ursa von Balthasara. Kraków: Wydawnictwo WAM.

Seckler, Max. 1964. Das Heil in Der Geschichte: Geschichtstheologisches Denken Bei Thomas von Aquin. München: Kösel-Verlag.

Sokolowski, Robert. 1995. The God of Faith and Reason: Foundations of Christian Theology. Washington: Catholic University of America Press.

Stolovič, Leonid Naumovič. 2008. Historia filozofii rosyjskiej. Podręcznik. Translated by Bogusław Żyłko. Gdańsk: Wydawnictwo słowo/obraz terytoria.

Strumiłowski, Jan Paweł. 2016. Piękno Zbawi Świat? Kraków: Wydawnictwo WAM.

Valliere, Paul. 2001. Modern Russian Theology. Bukharev, Soloviev, Bulgakov. Orthodox Theology in a New Key. Grand Rapids-Michigan: B. Eerdmans Publishing Company.

Walicki, Andrzej. 2005. Zarys Myśli Rosyjskiej. Od Oświecenia do Renesansu Religijno-Filozoficznego. Wyd. 1. Kraków: Wydawnictwo Uniwersytetu Jagiellońskiego. 